\title{
Higher Education and Globalization in the Context of the COVID-19 Crisis
}

\section{Ion Stavre}

Associate Professor, PhD, National University of Political Studies and Public Administration (SNSPA)

Monica Ilie-Prica

Postdoctoral Researcher, PhD, National University of Political Studies and Public Administration (SNSPA)

\section{Abstract}

The competition of civilizations forced the European universities to adapt to the competition with the Chinese and American universities. European integration cannot advance without the collaboration between European universities. An answer to these challenges is the CIVICA project, the European University of Social Sciences, a consortium of the following universities: Bocconi University (Italy), Central European University (Hungary), European University Institute (European Intergovernmental Organization), Hertie School of Governance (Germany), The National University of Political Studies and Public Administration (Romania), Sciences Po (France) and the School of Economics in Stockholm (Sweden). This experiment aims to become one of the European pilot universities, in the first round of applications for Erasmus+ in February 2019. The experiment takes into consideration the most important resource of a country: the human resource. The network of universities that are part of the CIVICA consortium will group approximately 38,000 students, 7,000 teachers and 3,000 people from the administrative apparatus. The London School of Economics is part of the CIVICA consortium, as an associate partner. At the Bucharest conference, the public presentation of the consortium and its objectives, the rectors of the seven universities set out to educate the future generations of professionals in social sciences, in order to solve the most pressing problems of the world. Creating a European identity is essentially the long-term, fundamental objective of the CIVICA consortium. In the context of this conference, we interviewed a few representatives of CIVICA, and their answers will be analyzed in this paper's section dedicated to the results of the research.

Keywords: globalization, higher education, CIVICA, E-learning, Covid-19 


\section{Introduction}

Recent years have shown that in order to survive in a globalized world, institutions, citizens and society as a whole must adapt to trends of uniformity and the expansion of ideas and practices in various fields, including higher education. In Romania, top institutions, like The National University of Political Studies and Public Administration (SNSPA), have embraced the opportunities offered by globalization or, at least, agreed to join a "European family" of prestigious universities. The example we will focus on in this paper is the entry of SNSPA in the consortium CIVICA European University, which includes other important universities, such as Sciences Po, Bocconi University and Hertie School of Governance, and London School of Economics is, also, partner in this project.

It is necessary to understand that in the new decade we have an obligation to be more open than ever to changes and challenges, as we have already felt such phenomena due to the COVID-19 pandemic, which led to the closure of universities. Since March, distance learning has been used in Romania, through e-learning platforms specially created for teachers and students, so as not to miss a semester of studies. At the same time, however, we must be aware that investments in modern distance communication technology via the Internet are mandatory. SNSPA, more precisely the College of Communication and Public Relations, has a multimedia laboratory, with high-performance equipment to offer multiple educational services in such a way that teachers can record courses for students or make videos. In addition, there is the issue of copyright. If these creations of the teachers are available for free on the Internet, YouTube, Facebook and other social networks, such teaching resources could be illegally copied by third parties and thus lead to conflicts and unwanted litigation. Therefore, it is preferable that the publication of teaching materials that are normally discussed at the university, at a course or seminar, be conditioned by an access password, so that only certain people can see and download those materials.

In Romania, the Ministry of Education and Research has entered into a partnership with the Romanian Television (TVR), through which the 8th and 12th grade students will be offered courses on the TVR2 channel in order to prepare for the National Evaluation and Baccalaureate. The admission of high school students and, respectively, the admission of students to college depend on the results of these exams. Universities, including SNSPA, have introduced online admission for future students, both for submission of papers and for the actual examination, and the average in the 11th grade, and not the 12th grade, will count in the tie between candidates. The same procedure was introduced for the master's degree, mainly consisting not necessarily of an actual exam, but a letter of intent.

As for the university graduation exams, they are also taken online, on the university platform. This is a completely new system for everyone, as it is really unusual to take the exam from home, from a distance, even more because it is a work of capital importance in a young person's career. It remains to be seen what the consequences 
of such actions will be. Even if they were difficult, these decisions were mandatory so as not to endanger the health and even the lives of students and teachers, knowing that the COVID-19 virus is highly contagious and is spreading rapidly, as there is no vaccine to fight it at the moment.

Beyond the coronavirus pandemic, we are facing a new decade of the 21st century, a century of speed, high-tech, robotics and digitalization. It is inconceivable to live a day of our lives without using the smartphone or other mobile devices, or the Internet, which offers endless possibilities today, from e-commerce to courses and even prescriptions sent by the family doctor for those who can't or may not go to the office. Many imagined the fight against the coronavirus as an invisible war, without weapons, but with an even greater psychological and economic impact than in the case of a real war. The crisis we are facing will affect us, experts say, at least 2-3 years from now, and this year 2020 is a difficult one for everyone, including the education system that needs to be rethought and adapted to the new requirements imposed by this challenging context. We certainly live in a new world and we must learn how to respond, on the one hand, to the threats and, on the other hand, to the opportunities of the contemporary era, but also to the phenomenon of globalization, which has been noticed since the 20 th century.

\section{Literature Review}

In a study conducted in Romania during the coronavirus pandemic (Florian \& Toc, 2020 ), it was found that there is an inequality of opportunities in education, one of the fundamental challenges of the Romanian education system. Romanian society is polarized, with a great number of young people at risk of poverty or social exclusion, with a high percentage of young people living in overcrowded housing and an inefficient social protection system. In the context of the interruption of the usual activities, generated by the pandemic with SARS - CoV - 2, the socio-economically disadvantaged students are more likely to disconnect from school. Disconnection from school is closely linked to early school leaving and poor school results. We could say that these poor school results have a negative impact on the university environment, because, in time, there will not be enough candidates, and the absence of students, at least in the case of private universities, will lead to their bankruptcy and dissolution.

Another aspect is the need for the development of digital skills and the use of new technologies among teachers, in particular for adapting teaching content and activities to the requirements of online tools. The Ministry of Education does not assume responsibility for ensuring free access to education for all students in the context in which $38 \%$ of children and young people under 16 are in a precarious financial situation aggravated by the restriction of economic activities. It is obvious that in this school year, but certainly in the next one, the educational system is and will be affected by the evolution of the SARS epidemic - CoV - 2. Mobile phone access to the Internet may not be enough to support a long learning process, in the context 
in which the transition to online involves more than meetings through audio-video platforms or topics sent through messaging applications. The entire teaching / learning methodology must be transferred online, requiring a systematic reorganization of the learning process through the computer (Florian \& Toc, 2020, p. 13).

Since 2014, the European Council has recommended to EU Member States an improvement in teachers' digital skills: "The rapid spread of digital learning tools and open educational resources also creates the need for teachers to gain a sufficient understanding of them in order to develop relevant digital skills and use them effectively and appropriately in teaching. These new tools can also help to ensure equal access to high quality education for all." (Official Journal of the European Union, C 183, 2014, p. 23)

Globalization has a major role in higher education and for this it is necessary for the countries to have superior technological preparation. As stated by Varghese (2013), „knowledge-based production has become the distinguishing characteristic of globalized economies. The intellectual capital produced by universities and research institutions has become a crucial factor of production in a globalized knowledge economy. Technological developments, especially in information technology transformed the way the world economy is organized and the way higher education is provided". (p. 7) The so-called 'academic capitalism', a term introduced by Slaughter and Leslie (1997), describes the 'marketization' of public higher education and the rise of research and development for commercial purposes, an aspect which is typical to globalization, too.

Since the medieval period, the academic institutions have played a significant role in the internationalization of knowledge, and the European model, particularly the Paris model, was the landmark, as many foreign students came from all over the world to study in such prestigious universities like Sorbonne. In the post-World War II period, the governments in the developed countries relied on higher education as a means for building relationships with foreign nations (Varghese, 2013, p. 9). In the era of globalization, the perceived role of universities changed from national development to contributing to producing for the global market. Universities became autonomous, less reliant on state funding, and market-oriented in their operations (Varghese, 2013). Higher-education institutions were thriving to reposition to remain relevant to the globalized production. The globalization of higher education was in response to these changes in the external context of education. The external context introduced changes whereby the process in higher education changed from internationalization to globalization. Internationalization of education implies the imparting of knowledge, skills, and values that have a universal application. Globalization implies a flow of people, knowledge, and culture across borders as a market-mediated process stemming from commercial motives. It is a designed activity to introduce an international and multicultural outlook to suit the requirements of the global market 
centered on knowledge economies. Economic rationality and commercial interests act as major incentives to promote cross-border education in the context of globalization. Institutions of higher education become yet other organizations engaged in producing and selling education to the global market, very often, for a profit. In other words, higher-education institutions become corporate entities functioning on the basis of the operating principles of the market process (Varghese, 2013, p. 9).

All the needed changes to reposition universities and to align with the requirements of the global market imply the globalization of higher education. Universities are revising their curricula, instruction methods, and language of instructions to reflect globalized higher education and promote cross-border education, which has become the means to globalize higher education. The most common form of cross-border education is through student mobility and institutional mobility. Increasing demand for the higher educated for the global market and an insatiate demand for highereducation degrees to enter the global market both put pressure on the cross-border institutions to offer courses and student places. Further, it has become an attractive area of investment at times producing more profit than in other sectors (Varghese, 2013, pp. 11-12). The cost of education and the visa rules became major factors influencing the choice of country for study by the cross-border students. In some countries, there is a provision to extend the visa for one year after the completion of studies while the students look for a job. The two factors that seem to influence demand for crossborder education may be employment opportunities and perceived high-quality education in the host country. A foreign degree enhances employment opportunities and higher returns to investment. Cross-border education became a source of future labor supply in the developed world since a majority of those who enter as students in the developed countries would like to stay there after their studies (Varghese, 2013, p. 15).

Many analysts have argued that the implications of globalization for higher education in particular are substantial, especially in terms of its relation to national development and to academic work within universities themselves. There are several reactions of higher education policy to globalization and its impact on changes at the institutional level. Significant per capita government budget reductions have been experienced in higher education with higher education institutions expected to do more with less, a significant push to diversify income by increasing nongovernmental resources from the private sector. Alternative sources include tuition/fee increases, the recruitment of overseas students paying full fees, competition for research grants and centers, more emphasis on consultancies, the packaging and marketing of various intellectual products, and appeals to alumni for gifts and bequests. An increased commodification of knowledge as intellectual property has occurred, particularly with regard to connecting the intellectual work of universities with community, business, and government interests and priorities. Reorganization of higher education has been promoted by national governments or in some cases 
state/provincial governments, to relate it more closely to national economic agendas. "Quality" movements in higher education have been established by governments, which are intended to monitor or audit institutional processes and outcomes, and funding is increasingly tied to the results. For example, in the United Kingdom, the external assessment of teaching and learning is done through both institutional and subject reviews and research performance is monitored separately. Concerns with social justice and equity issues in higher education have been evident and can be seen most clearly in expanding access to higher education in terms of numbers of places, and types of entry, and in increasing diversity of modes of study, both campus and technology-based. A preoccupation with higher education finance issues has developed at national levels. The increasing demand for higher education and the expansion of higher education systems at a time of constricting government budgets has resulted in financial crises for many universities. This in turn has led to considerable public debate about the appropriate balance of public versus private contribution to postsecondary education, and in particular the size of the student contribution in relation to government funding (Porter \& Vidovich, 2000, pp. 455457).

We find that the importance of higher education is reflected at both the individual and national levels, as universities can develop and compete in a globalized world. Globalization can bring new opportunities for universities and increase the cooperation between professors, students, scholars or researchers from all over the world.

A study carried out by SNSPA on access and equity in higher education showed that European policies on education and employment emphasize the need for further education for as many young people as possible, as this is the only way to which we can build a knowledge-based economy. Therefore, increasing the percentage of people who have completed high school and are still pursuing a university degree is a key objective of the European Union, both in the field of employment and education. The study also revealed an acute lack of information, both among school populations, parents, teachers, and among decision-makers about the concerns and training options of young people, on the one hand, and, on the other hand, the areas of intervention that should be taken into consideration by the competent institutions (Pricopie et al., 2011).

In the context of the coronavirus pandemic, Universities are taking intensive measures to prevent and protect all students and staff members from the highly infectious disease. Faculty members are already in the process of transitioning to online teaching platforms. Several universities have already suspended the semesterend final examinations, whereas continuous assessment will go on along with the online classes. The transition from face-to- face teaching to online delivery has a serious impact on assessments and evaluation. Technology in higher education is still under-developed and applying assessments online on those courses designed for 
face-to-face learning is a challenging task. Also lab tests, practices, and performance tests are not possible to conduct online. In addition, students who do not have an Internet facility will suffer a clear disadvantage while participating in the evaluation process, which would adversely affect their grade point averages (GPAs). The COVID19 pandemic may have a serious impact on the careers of this year's university graduates. They are experiencing major interruptions in teaching and assessment in the final part of their studies. They may likely graduate late due to the postponement of the final examination. Further, the graduates are going to face the severe challenges of the global recession caused by the COVID-19 crisis. It is the right time for faculty, students, and administrators to learn from this critical situation and to overcome these challenges. Online learning could be a greater opportunity as a result of this crisis. University authorities should encourage students and faculty to stay connected through the online or any social media platform and move forward together during this extremely difficult time. Faculty members should embrace technology and pay careful attention to student experiences to make the learning rich and effective (Sahu, 2020, pp. 3-5).

There are growing pressures on universities across the world to equip greater proportions of the population with higher order skills that can be used productively in the knowledge economy (Naidoo \& Jamieson, 2005, p. 38). With the pace of globalization accelerating and its impact expanding, universities have begun to change as well, seeing increasing numbers of students flow from beyond national borders, coordinating if not standardizing degrees and calendars, and collaborating both in research and in teaching. Despite these efforts, there is still no consensus about what globalization will ultimately mean for how universities educate students, interact with peers, collaborate with governmental and private partners, and define their fundamental missions (Dirks, 2015).

Globalization is also related to the idea of developing relations with different cultures. In responding to and giving expression to contemporary geopolitical shifts, universities around the world are increasingly entangled in intersecting local, national, and global relations. Transnational students are using the internationalization of higher education to extend and deepen their capacity for thinking and acting globally, nationally and locally in order to enhance the viability of their life trajectories (Singh, 2005, p. 9).

The international context of education has changed significantly over the last decade, and in today's more globalized world it is no longer possible to ignore the effects of global macro socio-economic changes on both national and local education systems. Emerging as part of the trend brought about by economic globalization is the focus on the internationalization of higher education. The internationalization of higher education might be understood as a response of higher education to globalization (Tuinamuana, 2005, p. 199). Moreover, the globalization processes "affect national education systems directly as well as indirectly in different ways. Most countries have 
restructured their education systems during the past two decades. The fact that the formulated policies are rather similar everywhere, indicates that ideas related to the construction of education have been borrowed from the world models" (Daun, 2005, p. 99).

Partnerships between universities are very important in a globalized world. The initiatives include various activities in the academic field, such as research, teaching, professional development, and mentoring. The National University of Political Studies and Public Administration (SNSPA) from Romania has become a member of the CIVICA consortium, which gathers major European universities in a major academic collaboration. This partnership and the opportunities that come with it are the topic of the analysis which will be presented in the following pages.

\section{Methodology}

The CIVICA consortium, European University of Social Sciences, is a consortium of the following universities: Bocconi University (Italy), Central European University (Hungary), European University Institute (European Intergovernmental Organization), Hertie School of Governance (Germany), National University of Political Studies and Public Administration (Romania), Sciences Po (France) and Stockholm School of Economics (Sweden). This experiment aspires to become one of the European pilot universities in the first round of Erasmus + applications in February 2019. The experiment considers a country's most important resource: human resources. The case of Finland is a successful example, which shows that a quality general education can lead to sustainable, economic and social development.

At the conference in Bucharest, for the public presentation of the consortium and its objectives, the rectors of the seven universities set out to educate future generations of social science professionals to solve the most pressing problems in the world. Creating a European identity is essentially the fundamental, long-term goal of the CIVICA consortium. In the context of this conference, we had the pleasure and honor of interviewing several representatives of CIVICA, and their answers will be analyzed in the section of the paper dedicated to research results.

The research method that was used was the interview. We interviewed 4 persons from the CIVICA consortium:

- $\quad$ Aurelien Krejbich (Sciences Po), executive director of CIVICA

- Karin Wistrom, director of Stockholm School of Economics Executive Education

- Nikolas von Hoffmann, Manager Office of the President (Hertie School of Governance)

- Kate Vivian, Deputy Vice President for International Affairs (Sciences Po) 
SNSPA is a partner in this consortium and organized at its headquarters a working meeting on February 4, 2020, attended by the Rector of SNSPA, Professor Remus Pricopie, $\mathrm{PhD}$, and guests from partner universities abroad and from state institutions in Romania, including the Ministry of Education and Research.

With this research, we aimed to find out what will be the role of CIVICA in the academic environment in Romania and how it will facilitate Romania's contacts with countries like Great Britain, Italy, Germany, Sweden, Hungary and others in this European partnership, because CIVICA is European University of Social Sciences.

The questions for the interview were:

What is your opinion about the CIVICA project?

What do you expect from this project?

What will be the structure of this collaboration?

What kind of programs do you intend to develop and how do you intend to apply the results of the research?

The answers offered by the persons who were interviewed will be analyzed in the section dedicated to "Discussion and Analysis”.

\section{Discussion and Analysis}

After the year 2000, globalization began to accelerate in all areas. Digital technology has changed everything and continues to bring fundamental changes to the daily lives of every European citizen. Education was an area that benefited from the momentum of an explosion of knowledge in all areas. Unfortunately, the European Union is not a global player in the digital world, if we think only of $5 \mathrm{G}$ technology, where it has only the role of added value for the two giants: the USA and China.

In the field of university education, we can easily identify two major models in the world: the European model and the American model. The European model is generally based on stable teaching positions, for an indefinite period, with compulsory retirement at the age of 65 . The best teachers are immediately called to the US where they can teach as much as they can physically. Funding is dominated by state budget revenues. Students may or may not pay tuition fees. The study organization model is known generically as the Bologna model.

American universities are organized according to another model. The funds are provided mainly by large American companies that recruit their future employees from universities. Students usually pay considerable fees, which have, among other things, a role of making students responsible, in order to determine them to treat the university period with the utmost seriousness. Research is a major component of activity in American universities, funded and supported by large American companies, which are ready to take the results of research and introduce them into 
industrial production or commercial activity, or the results in the field of social sciences.

Creating a European identity is very difficult and studies in the field of communication have shown that, at least so far, it has not been possible to create a European public sphere, in the sense proposed by Jurgen Habermas (2012).

In the short term, the project will contribute to a greater integration of the elites of the European Union countries. The spread of knowledge will accelerate, the best students will get to work in Western European companies. Global competition requires the concentration of the most enlightened minds for the development of the European Union, in the global competition with the USA and China. It remains to be seen how the smaller European countries will develop, which do not have the opportunity to pay the best graduates properly. Will the economic gaps increase or not? It is a question that will be answered in time.

An urgent issue that needs to be clarified within the CIVICA consortium is how to finance the consortium. Too much pressure on the national education budget for consortium projects could create a national rejection reaction.

The project is very ambitious, but beyond the optimism needed to start such an important collaboration, we can identify some elements that could hinder or even block the development of the project.

First of all, the fact that the university system has a very strong national color, would reiterate the dilemma of European integration: a Europe of nations or a Europe of regions? The year 2020 is the beginning of the work of the new European Commission, elected in 2019, which proposed as a strategy the European Green Pact - a roadmap to ensure the sustainability of the EU economy, by turning climate and environmental challenges into opportunities in all policy areas and by ensuring a transition that is fair to all and inclusive.

\section{(https://ec.europa.eu/romania/news/20191211_pactul_ecologic_european_ro)}

The CIVICA consortium should help raise awareness of environmental issues as part of a complex European awareness. This objective could face conflicting interests at the level of European countries. More specifically, sending rubbish from Western European countries to former communist states should no longer be possible in any form. Today we find that the export of garbage, disguised in various forms is expanding. The end of February was dominated in the Romanian media by the issue of burning waste from Great Britain to Romania, because destruction by burning in Great Britain costs 400 pounds / ton, and in Romania 30 euros / ton (Niculescu, 2020). From this perspective, environmental issues are seen differently in Romania and the United Kingdom.

Another example in the field of environmental protection that could generate differences of approach between EU member states is the logging of virgin forests in 
Romania, as a result of the complicity between the corrupt authorities in Romania and a well-known Austrian company. If CIVICA aims to contribute to the consolidation of a common European ecological consciousness, how will this consciousness be expressed in the case of the destruction of virgin forests in Romania? The situation is so serious that on February 12, 2020, the European Commission activated the infringement procedure for Romania due to illegal deforestation. There was no consistent civic reaction in either Romania or Austria. The consortium explicitly aims, at the licensing level, to focus in particular on civic engagement.

The network of universities that are part of the CIVICA consortium will group approximately 38,000 students, 7,000 teachers and 3,000 people from the administrative apparatus. The London School of Economics is also part of the CIVICA consortium, as an associated partner.

At the conference in Bucharest, for the public presentation of the consortium and its objectives, the rectors of the seven universities set out to educate future generations of social science professionals to solve the most pressing problems in the world. Creating a European identity is essentially the fundamental, long-term goal of the CIVICA consortium. In the context of this conference, we had the pleasure and honor of interviewing several CIVICA representatives, and in the following we will analyze the answers provided by CIVICA representatives in the interviews. These answers reflect the mission and vision of CIVICA, the way the activity is carried out, the benefits offered to students and teachers and the perspectives regarding the development of this educational project in the future.

Aurelien Krejbich (Sciences Po), Executive Director CIVICA, Sciences Po:

"I have a very positive impression about the project. It's a very inspiring initiative to gather such a nice selection of great institutions in the social sciences. My priority are the students, I really want to make the difference on the ground and to make sure we can offer interesting and exciting opportunities for the students in terms of mobility, degrees, access to libraries, sports, cultural events. My main ambition is to make sure that for the students, CIVICA is a true experience (...). CIVICA is a pilot programme (...). The idea is to create a platform, to create a market of positions for young researchers where they could identify with themselves within a European model and start their career in Europe."

Karin Wistrom, Director of the Stockholm School of Economics Executive Education:

"We are very much looking forward to work together as a truly European university, with this great spread that we have and the different perspectives, from Sweden in the north to Romania in Southeast Europe so we think this opportunity is going to be a fantastic offer for our students, and also work together, both as faculty and the staff (...). We will work together with the Bachelor programme to offer the students the opportunity to study at various, different places and we hope also in the future to be able to do executive education studies together." 
Nikolas von Hoffmann, Manager Office of the President, Hertie School of Governance:

"We want professors, students, staff at the universities to really develop this alliance together. There is a clear work programme that we have that involves joint courses and research cooperation, student ambassadors that we will set up (.). Over time, we will move into developing degree programmes for students and really relevant topics for all of the European Union at this stage, what's going to be the future of Europe, how to deal with climate change and changes in the environment and the future of democracy and also how we can use data better to inform research in social sciences."

Kate Vivian, Deputy Vice President for International Affairs, Sciences Po:

"The focus is very much on we can innovate within a university environment at a collaborative level, so we're on a European level, how we can work together to create new, exciting opportunities for students and to provide also opportunities to respond to very serious challenges facing Europe and the world today. So that takes a huge amount of diverse forms: joint courses that are going to be across the network between two, three or maybe more institutions where students will be able to learn and benefit from faculty and classes and students amongst the institutions. I am thinking about collaborative research, exciting initiatives, such as the sports tournament. There are a whole range of opportunities for us to collaborate at every level and to really ensure that we are creating something new and dynamic (.). We will create knowledgebased teams that will be both researchers, faculty, but also students, who will be working collaboratively together to produce solutions, recommendations on different topics that can be used in the political perspective, for public policy orienting, as community outreach engagement tools, as well, so as knowledge for the greater community."

The answers offered by the interviewees show us that CIVICA is an ambitious, futureoriented project, focused on quality higher education, on providing a useful educational experience for students and teachers, on collaborative research, on the exchange of experience between universities, etc. We identified a few key words, such as "true experience" and "platform" (Krejbich), "alliance" (von Hoffmann), "executive education studies" (Wistrom), "network", "knowledge-based teams" and "collaborative" research "(Vivian).

As we have seen in the literature review section, university education occupies an essential place in a globalized world. Universities seek to form partnerships based on specializations and sometimes according to geographical criteria, and the faculty, researchers and students communicate in a real international academic network. Of course, funds are also important. In Romania, according to the law, universities have autonomy and manage their human and material resources according to the particular situation of each of them. Some perform and become known abroad, others remain in a certain place nationally. SNSPA is a relatively young university, founded in 1991, after the 1989 Revolution, has graduates who now work in various fields, from communication and public relations, to politics, diplomacy and public 
administration, some of them becoming prominent members of the European Parliament.

In the conclusion of the data analysis, we can say that CIVICA is a very good opportunity for the Romanian academic field to be part of the elite of European universities, especially those focused on social sciences, even more because we have the experience of the successful Erasmus + program. All these are a proof of the opening of Romanian education abroad, thus keeping pace with the globalized world and with the challenges that are affecting us, such as the COVID-19 pandemic. We can also say that the pandemic has accelerated the collaboration between European universities. London School of Economics, probably one of the best schools of Economics in the world, is part of the CIVICA consortium, as an observer. British participation is essential because in this collaboration the EU membership is not important. The pandemic did not take account of this aspect of membership.

The crisis generated by the COVID-19 pandemic needs special attention in matters of education through e-learning. It is necessary to focus on the technological requirements in this period. In the case of the College of Communication and Public Relations (National University of Political Studies and Public Administration), for instance, we use a platform where we can upload courses that are accessed by students with username and password. Also, electronic mail and social media are used in order to communicate with our students. In the future, the equipment for distance learning needs to be improved and adapted to the various methods of teaching and evaluating students who take online courses and seminars. Currently, an expert team is working on several scenarios for the opening of schools and universities in September 2020, depending on the evolution of the coronavirus pandemic.

\section{Conclusion}

In parallel with the challenges imposed by the phenomenon of globalization, the COVID-19 pandemic crisis has generated major changes. Universities around the world, including those in Romania, had to adapt their courses and seminars to the new conditions - everything is now online, including graduation and college entrance exams. Teachers and students keep in touch through various platforms, but the problem is given by the difficult access, for some, to the Internet and mobile devices, such as tablets. In pre-university education, the situation is even more dramatic, as there are few children (especially those in rural areas) who have access to the Internet. The Ministry of Education is obliged to find solutions for all pupils and students, as well as for teachers, so that the school is not too much affected by the negative effects of the crisis generated by COVID-19.

In addition, globalization has imposed a different strategy at the university level, topics such as attracting funds and preparing students to become specialists in important institutions being on the agenda. A network of universities facilitates a 
medium and long-term partnership, with benefits for all parties involved, as long as the collaboration will be very good and will allow students and faculties to have an educational experience that is really "a true experience", as mentioned by the coordinator of the CIVICA project, Mr. Aurelien Krejbich.

But, at the same time, we need to pay attention to the challenges of the global crisis, caused by the coronavirus pandemic, but also to the changes in various areas, including education and health, in terms of technological requirements. Artificial intelligence and digitalization are essential factors in the development of today's society and higher education plays a major role in preparing new generations of specialists to work in different places and assume responsibility in a globalized world.

\section{References}

[1] Daun, H. (2005). Globalisation and the governance of national education systems. In Joseph Zajda (coord.). International Handbook on Globalisation, Education and Policy Research. Global Pedagogies and Policies (pp. 93-107). Springer.

[2] Dirks, N. (20 Jan. 2015). How are universities adapting to globalization?. Available at: https://www.weforum.org/agenda/2015/01/how-areuniversities-adapting-to- globalization/.

[3] Florian, B., Toc, S. (April 2020). Policy note. Educatia in timpul pandemiei. Raspunsuri la criza nesfarsita a sistemului educational romanesc, Bucharest. Available at: http://snspa.ro/wp-content/uploads/2020/04/Policy-noteeducatie_final.pdf.

[4] Habermas, J. (2012). Despre Constitupia Europei, Bucharest, Comunicare.ro.

[5] Naidoo, R., Jamieson, I. (2005). Knowledge in the Marketplace: The Global Commodification of Teaching and Learning in Higher Education. In Peter Ninnes \& Meeri Hellsten (coord.). Internationalizing Higher Education. Critical Explorations of Pedagogy and Policy (pp. 37-51). Springer.

[6] Niculescu, M. (March 2020). Ministrul Mediului a gasit sursa poluarii masive din Bucuresti: „Nu toleram ca Romania sa ajunga groapa de gunoi a Europei”. Libertatea. Available at: https://www.libertatea.ro/stiri/ministrul-mediului-agasit-sursa-poluarii- masive-din-bucuresti-arderea-gunoaielor-importate290048.

[7] Porter, P., Vidovich, L. (2000). Globalization and higher education policy. Educational Theory, 50(4), 2000, 449-465.

[8] Pricopie, R., Frunzaru, V., Corbu, N., Ivan, L., Bargaoanu, A. (2011). Acces si echitate in invatamantul superior. Dialog cu elevii si studentii, Bucharest, Comunicare.ro.

[9] Sahu, P. (2020). Closure of Universities Due to Coronavirus Disease 2019 
(COVID- 19): Impact on Education and Mental Health of Students and Academic Staff. Cureus, 12(4), 1-6.

[10] Singh, M. (2005). Enabling Transnational Learning Communities: Policies, Pedagogies and Politics of Educational Power. In Peter Ninnes \& Meeri Hellsten (coord.). Internationalizing Higher Education. Critical Explorations of Pedagogy and Policy (pp. 9-36). Springer.

[11] Tuinamuana, K. (2005). International Policy Convergence in Higher Education: An Analysis from the Periphery. In Peter Ninnes \& Meeri Hellsten (coord.).

[12] Internationalizing Higher Education. Critical Explorations of Pedagogy and Policy (pp. 199-213). Springer.

[13] Varghese, N. V. (2013). Globalization and higher education: Changing trends in cross border education. Analytical Reports in International Education, 5(1), 7-20.

[14] https://ec.europa.eu/romania/news/20191211_pactul_ecologic_european_r o 